\title{
TANGGUNG JAWAB NOTARIS DALAM PEMBUATAN PERJANJIAN SUBROGASI DENGAN JAMINAN HAK ATAS TANAH DI KOTA BATAM
}

\author{
Agus Riyanto ${ }^{1}$ \\ ${ }^{1}$ Dosen Program Studi Ilmu Hukum, Fakultas Sosial Dan Humaniora, Universitas \\ Putera Batam, Batam, Jl Letjen R. Soeprapto, Kampus UPB, Batam 29442, Indonesia
}

Penyesuaian Pengarang E-mail: gus.ryant00@gmail.com

No Hp: +6281372270867

\begin{abstract}
ABSTRAK
Perbankan memiliki posisi strategis sebagai lembaga intermediasi dan penunjang sistem pembayaran. Untuk menjamin pinjaman atau pembiayaan yang diberikan bank kepada debitur atau nasabah, maka bank akan membebankan agunan kepada nasabah. Dalam praktek, kredit yang sudah dijamin dengan agunan seringkali dilakukan take over. Take over dipilih masyarakat karena dengan berbagai alasan, misalnya prosedur kredit yang sederhana dan waktu yang dibutuhkan juga relatif cepat. Penelitian ini mencoba menganalisis pertanggungjawaban Notaris dalam pembuatan perjanjian take over khususnya jika pinjaman/kredit dijamin dengan hak atas tanah. Metode yang digunakan dalam penelitian adalah normatif, dimana peneliti memperoleh data dari studi pustaka yang kemudian akan diuji dengan asas-asas hukum. Hasil penelitian menunjukkan bahwa dalam pembuatan akta perjanjian take over, pada hakekatnya Notaris memiliki tanggung jawab baik secara moral maupun hukum.
\end{abstract}

Kata Kunci: Notaris, Take Over, Agunan, Pertanggungjawaban

\section{ABSTRACT}

Banking has a strategic position as an intermediary institution and support payment system. To guarantee the loan or financing provided by the bank to the debtor or customer, the bank will charge the collateral to the customer. In practice, credit already secured by collateral is often carried out take-over. Take over is chosen by the community because for various reasons, such as simple credit 
proceaures ana the tume requirea is atsoretattvetyjast. This research trtes to analyze the responsibility of Notary in making takeover agreement specially if loan / credit is secured with right of land. The method used in this research is normative. Where researchers get data from literature studies which will then be tested with legal principles. The result of the research shows that in the making of deed of take over agreement, in essence Notary has responsibility both morally and law.

Key word: Notary, Take Over, Collateral, Accountability

\section{I.PENDAHULUAN}

\subsection{Latar Belakang Masalah}

Bank adalah perantara antara pihak-pihak yang mempunyai kelebihan dana (surplus of fund) dengan pihakpihak yang kekurangan dan memerlukan dana (lack of fund). Oleh karena itu, perbankan akan bergerak dalam kegiatan perkreditan dan berbagai jasa yang diberikan, bank melayani kebutuhan pembiayaan serta melancarkan sistem pembangunan (Djumhana, 2000: 1). Salah satu bentuk pembiayaan kepada masyarakat yang dilakukan pihak perbankan adalah pemberian kredit/pinjaman dengan berbagai nama dan fasilitas. Disatu pihak, bank sesuai dengan fungsi utamanya dan berdasarkan kenyataan bahwa pemberian kredit atau penempatan dana dalam fasilitas kredit adalah usaha yang paling besar memberikan pendapatan, namun di lain pihak hal itu banyak mengandung resiko (Suwandi, 2006).

Secara etimologis istilah kredit berasal dari bahasa latin, credere, yang berarti kepercayaan. Istilah kredit perbankan hampir dipersamakan dengan hutang piutang pada umumnya, meskipun dalam hukum perdata, antara utang dan kredit merupakan dua perbuatan hukum yang berbeda sehingga memiliki konsekuensi yuridis 
yang berbeda juga (Harun, 2010:1). Dalam operasional perbankan, terdapat prinsipprinsip tertentu yang melandasi perkreditan itu sendiri, prinsipprinsip tersebut antara lain:

1. Prinsip kepercayaan;

2. Prinsip kehati-hatian;

3. Prinsip Sinkronisasi;

4. Prinsip perbandingan antara pinjaman, modal dan aset; dan

5. Prinsip 3 R. Dalam prinsip ini harus memperhatikan juga faktor-faktor sebagai berikut:

a.returns : harus ada pengembalian/ hasil dari debitur

b.repayment: ada kemampuan bayar dari debitur

c.risk bearing:

kemampuan menahan resiko dari debitur harus baik (Hasibuan, 2008: 106).

Berdasarkan jangka waktu dan penggunaanya kredit dapat digolongkan menjadi 3 (tiga) jenis, yaitu:

1.Kredit investasi, yaitu kredit jangka menengah atau panjang yang diberikan kepada debitur untuk membiayai barang-barang modal;

2.Kredit modal kerja, yaitu kredit yang diberikan baik dalam rupiah maupun valuta asing untuk memenuhi modal kerja yang habis dalam satu siklus usaha dengan jangka waktu maksimal 1 (satu) tahun;

3.Kredit konsumsi, yaitu kredit jangka pendek atau panjang yang diberikan kepada debitur untuk membiayai barang-barang kebutuhan atau konsumsi dalam skala kebutuhan rumah tangga yang perlunasannya dari penghasilan bulanan nasabah debitur yang bersangkutan (Ais, 2011: 60-61). Apabila debitur berkeinginan agar proposal kredit disetujui oleh perbankan, biasanya permohonan/aplikasi 
kredit tersebut dilengkapi

dengan melampirkan semua

dokumen pendukung yang dipersyaratkan (Taufik, 2011:

47). Selanjutnya, dari track record nasabah yang ada, diadakan pengelompokan pengelompokan tertentu yang didasarkan atas kelancaran usaha dan sektor usaha secara lengkap. Pengelompokan tersebut antara lain:

1.Kredit lancar

2.Dalam perhatian khusus

3.Kredit kurang lancar

4.Kredit diragukan

5.Kredit macet (Iskandar, 2008: 184).

Pelaksanaan kredit agar berjalan lancar, atau untuk mengantisipasi sewaktu-waktu jika kredit macet, suatu pinjaman diatur dalam suatu perjanjian/akad kredit. Akad yang dibuat antara bank dengan nasabah dituangkan dalam bentuk akad baku (Usanti, 2013: 47). Perjanjian pemberian kredit di dalamnya terkandung unsur-unsur kepercayaan, tenggang waktu, degree of risk, danprestasi (Djumhana, 2000: 370-371). Hal ini berarti bahwa terjadi suatu tenggang waktu antara perjanjian pinjam meminjam dibuat dengan saat pengembaliannya. Adanya tenggang waktu tersebut membuat bank menanggung risiko dari kemungkinan debitur tidak mampu mengembalikannya. Akad kredit didasarkan atas perjanjian pinjam meminjam, sebagaimana dimaksud dalam Pasal 1754 KUH Perdata, bahwa pinjam-meminjam ialah perjanjian dengan mana pihak yang satu memberikan kepada pihak yang lain suatu jumlah tertentu barang-barang yang menghabis karena pemakaian, dengan syarat bahwa pihak yang belakangan ini akan mengembalikan sejumlah yang sama dari macam dan keadaan yang sama (Suwardi, 2010: 74).

Untuk menjamin pinjaman atau pembiayaan yang 
diberikan bank kepada debitur atau nasabah, maka bank akan membebankan agunan kepada nasabah. Secara teoritis, menurut Vollmar, dalam Pasal 1131 KUHPerdata dijelaskan bahwa segala kebendaan seorang, baik yang bergerak maupun yang tak bergerak, baik yang sudah ada maupun yang baru akan ada dikemudian hari menjadi tanggungan untuk segala perikatannya perseorangan (Sulastri. 2011: 85). Pembebanan jaminan tersebut dilakukan perbankan dalam rangka penerapkan suatu prinsip kehati-hatian. Prinsip kehati-hatian wajib dilaksanakan oleh pihak perbankan mengingat uang yang dipinjamkan oleh bank kepada para debitur adalah uang atau dana masyarakat yang disimpan oleh bank (Suwardi, 2010: 75).

Di samping jaminan, bentuk lain dari penerapkan prinsip kehati-hatian adalah kewajiban untuk menerapkan prinsip mengenal nasabah. Setiap orang yang melakukan usaha dengan penyedia jasa keuangan harus menyerahkan identitas diri secara lengkap (Adityananta, 2013). Cepat atau lambat semua industri perbankan Indonesia harus menerapkan prinsip KYC (Know Your Customer) ini. Meskipun dari segi operasional perbankan, barangkali bukan pekerjaan yang mudah untuk melaksanakan prinsip KYC (Know Your Customer) ini (Erdiansyah, 2012). Terkait take over, bank selalu menyarankan agar mengadakan pengalihan hak secara resmi atau dengan alih debitur demi menghindari segala resiko yang dapat saja terjadi dimasa yang akan datang karena lamanya masa angsuran yang akan diteruskan oleh pihak penerima pengalihan hak atau pelimpahan kewajiban angsuran (Soerjopratiknjo, 1984: 18). Di perbankan, proses take over di atas harus dilakukan secara 
hati-hati. Hal itu agar jangan sampai kredit yang ditake over ke debitur baru akan menimbulkan permasalahan dikemudian hari, termasuk kepastian hukum mengenai dapat atau tidaknya jaminan untuk dieksekusi apabila nantinya mengalami macet. Untuk itu, pihak perbankan biasanya mengharuskan nasabah untuk melakukan perjanjian di hadapan notaris dalam pembuatan perjanjian take over, termasuk untuk mengikat jaminan.

1.Perjanjian take over atau peralihan kredit identik dengan peristiwa subrogasi sesuai Pasal 1400 KUH

Perdata. Pasal tersebut mengatur bahwa subrogasi adalah perpindahan hak kreditor kepada seorang pihak ketiga yang membayar kepada kreditor, dapat terjadi karena persetujuan atau karena undang-undang. Peristiwa yang terjadi pada peralihan kredit memenuhi unsur-unsur yang terdapat dalam subrogasi.

(Suharnoko, 2005: 1). Unsur-unsur yang terdapat dalam subrogasi adalah:

a.Penggantian hak kreditur oleh pihak ketiga;

b.Adanya pembayaran yang dilakukan pihak ketiga terhadap kreditur; dan

c. Terjadi baik karena perjanjian atau undangundang (Satrio, 1999: 50). Tan Thong Kie menjelaskan bahwa para pihak dalam subrogasi ada 3 yaitu kreditur awal, debitur dan pihak ketiga.

Pihak ketiga dalam subrogasi ini bisa siapa saja, selama ada pihak lain yang membayar hutang atau kredit kepada kreditur dan memposisikan dirinya untuk menjadi kreditur baru maka ia disebut pihak ketiga (Kie, 2007: 683-687). Terdapat 2 (dua) cara terjadinya 
subrogasi, yaitu (Satrio, 1999: 65):

1)Terjadi karena persetujuan yang dapat berasal dari inisiatif kreditur maupun debitur;

2)Terjadi karena undangundang. Subrogasi ini diatur dalam Pasal 1402 KUHPerdata yang menyatakan bahwa subrogasi terjadi pada saat seorang kreditur yang melunasi hutang seorang debitur kepada seorang kreditur lain yang berdasarkan hak istimewa atau hipotiknya mempunyai hak yang lebih tinggi daripada kreditur pertama.

\section{Kewenangan Notaris}

Menurut Emma Nurita,

Jabatan Notaris merupakan suatu jabatan yang sangat mulia, mengingat peranan Notaris sangat penting bagi lalulintas

kehidupan

masyarakat, maka perilaku dan perbuatan Notaris dalam menjalankan jabatan profesinya haruslah sesuai dengan kode etik seorang Notaris (Sundah, 2014: 36).

$$
\text { Lembaga }
$$

Notaris

masuk di Indonesia pada permulaan abad ke-17. Pada tahun 1860, pemerintah Hindia Belanda menganggap perlu untuk membuat peraturan yang baru bagi jabatan Notaris di Nederland Indie untuk disesuaikan dengan peraturan jabatan Notaris yang berlaku di Belanda. Setelah Indonesia merdeka, keberadaan lembaga Notaris di Indonesia tetap diakui berdasarkan Pasal II Aturan Peralihan UUD 1945 (Adjie, 2008: 3).

Saat ini peraturan yang berlaku adalah UndangUndang Nomor 30 Tahun 2004 tentang Jabatan Notaris sebagaimana telah diubah dengan Undang-Undang 
Nomor 2 Tahun 2014 (UU

Jabatan Notaris).

Produk notaris adalah akta otentik. Dalam Pasal 1868 KUHPer dinyatakan bahwa suatu akta otentik ialah akta yang dibuat dalam bentuk yang telah ditentukan oleh undang-undang, dibuat oleh atau di hadapan pejabat umum yang berkuasa untuk itu di tempat dimana akta itu dibuat. Akta Notaris yang dibuat oleh pejabat umum disebut akta pejabat / akta relaas (ambtelijke acte), merupakan akta Notaris yang hanya memuat apa yang dialami, didengar dan disaksikan oleh Notaris sebagai pejabat umum (Mulyoto, 2010: 43).

Kewenangan notaris sebagai pejabat umum untuk membuat akta otentik diatur dalam Pasal 15 UU Jabatan Notaris, yakni:

(1) Notaris berwenang membuat Akta autentik mengenai semua perbuatan, perjanjian, dan penetapan yang diharuskan oleh peraturan perundangundangan dan/atau yang dikehendaki oleh yang berkepentingan untuk dinyatakan dalam Akta autentik, menjamin kepastian tanggal pembuatan Akta, menyimpan Akta, memberikan grosse, salinan dan kutipan Akta, semuanya itu sepanjang pembuatan Akta itu tidak juga ditugaskan atau dikecualikan kepada pejabat lain atau orang lain yang ditetapkan oleh undang-undang.

3.Hak Atas Tanah

Pengertian"penguasaan" dan"menguasai" dalam Pasal 33 ayat (3) UUD 45 dan Pasal 2 UUPA dipakai dalam aspek publik. Selanjutnya berdasarkan Pasal 2 UUPA ayat (2) ditentukan bahwa hak menguasai dari Negara tersebut memberi wewenang kepada Negara untuk :

a. Mengatur dan 
menyelenggarakan

peruntukan,

penggunaan, persediaan, pemeliharaan bumi, air, dan ruang angkasa tersebut.

b. Menentukan

dan mengatur hubunganhubungan hukum antara orang-orang dengan bumi, air dan ruang angkasa.

c. Menentukan

dan

mengatur hubungan-hubungan hukum antara orang-orang dan perbuatan-perbuatan hukum yang mengenai bumi, air, dan ruang angkasa.

Berkaitan dengan hak atas tanah diatur dalam Bab I UUPA dimana di dalamnya mengatur tentang pendaftaran tanah, air, dan ruang angkasa. Hak-hak atas tanah tersebut diatur di dalam Pasal 16 UUPA ayat (1) yang terdiri dari:

\section{Hak milik}

2.Hak guna usaha

3.Hak guna bangunan

4.Hak pakai
5.Hak sewa

6.Hak-hak lain yang diatur di dalam perundang-undangan lain:

a. Hak pengelolaan

b. Hak menguasai hutan

Dengan demikian tanah yang terdapat hak-hak atas tanah tersebut dapat dimiliki dan dipunyai oleh orang, badan hukum atau beberapa orang bersama-sama, tetapi tentunya dengan batasan-batasan yang telah diatur oleh peraturan pemerintah dan tidak sematamata untuk kepentingan pribadi karena "semua tanah mempunyai fungsi sosial”. Tanah yang semakin langka dapat dipergunakan seefisien mungkin sehingga sesuai tujuan UUPA menunjang terbentuknya sesuatu masyarakat adil dan makmur (Soetiknjo, 1990: 53). Berdasarkan latar belakang di atas, kami tertarik untuk mengkaji lebih lanjut dalam sebuah penelitian yang berjudul "Tanggung Jawab Notaris Dalam Pembuatan Perjanjian 
Take Over Dengan Jaminan

Hak Atas Tanah di Kota Batam"

\subsection{Rumusan Masalah}

Berdasarkan latar belakang penelitian di atas, maka rumusan masalah yang kan diteliti diantaranya:

1.Bagaimana tanggung jawab

Notaris dalam pembuatan perjanjian take over dengan jaminan hak atas tanah di Kota Batam?

2.Tindakan-tindakan apa yang dilakukan Notaris agar perjanjian take over dengan jaminan hak atas tanah dapat menjamin rasa aman bagi para pihak.

\section{METODE PENELITIAN}

Adapun metode penelitian yang digunakan oleh penulis adalah kualitatif dengan menggunakan pendekatan yuridis. Sumber data yang digunakan dalam penelitian ini adalah data data sekunder.
III HASIL PENELITIAN DAN PEMBAHASAN

Tanggung Jawab Notaris Dalam Pembuatan

Perjanjian Take Over Dengan Jaminan Hak Atas Tanah Di Kota Batam

Pengaturan mengenai hak atas tanah di Kota Batam berbeda apabila dibandingkan dengan daerah lain di Indonesia. Mayoritas, masyarakat di Kota Batam menguasai rumah mereka dengan alas hak berupa Hak Guna Bangunan (HGB). Hal ini barangkali merupakan kebijakan pemerintah pusat yang memberikan kewenangan kepada Otorita Batam (saat ini bernama

Badan

pengusahaan/BP Batam) bahwa seluruh tanah di Kota Batam diberikan kepada Otorita Batam dengan hak pengelolaan.

Kewenangan Otorita

Batam melalui Hak Pengelolaan di atas berdasarkan Keppres Nomor 41 Tahun 1973 tentang Kedudukan Pulau Batam 
sebagai daerah industri. Pasal 6

ayat (2) menyebutkan bahwa hal-hal yang bersangkutan dengan pengurusan tanah di dalam wilayah daerah industri Pulau Batam dalam rangka ketentuan tersebut diatur lebih lanjut oleh Menteri Dalam Negeri sesuai dengan peraturan perundang-undangan yang berlaku dibidang agraria dengan ketentuan seluruh area tanah yang terletak di Pulau Batam diserahkan dengan Hak Pengelolaan kepada Ketua Otorita Pengembangan Daerah Industri Pulau Batam.

Ketentuan

tersebut

memberikan kewenangan kepada Pihak Ketua Otorita Pengembangan Daerah Industri Pulau Batam untuk :

1.Merencanakan peruntukan dan penggunaan tanah tersebut;

2.Menggunakan tanah tersebut untuk keperluan pelaksanaan tugasnya;

3.Menyerahkan bagian-bagian dari tanah tersebut kepada pihak ketiga dengan Hak Guna Bangunan atau Hak Pakai. (HGB berlaku selama 30 tahun dan dapat diperpanjang 20 tahun kemudian dapat diperbaharui 30 tahun lagi dan seterusnya sedangkan Hak Pakai berlaku selama 10 tahun dan dapat diperpanjang setiap 10 tahun sejauh yang bersangkutan masih menggunakan tanah tersebut sesuai dengan peruntukannya);

4.Menerima uang pemasukan dan uang wajib tahunan (Uang Wajib Tahunan Otorita Batam "UWTO”). Tanah misalnya berstatus Hak Guna Bangunan yang akan dijaminkan di suatu bank harus dipastikan terlebih dahulu terkait jangka waktunya. Untuk tanah yang akan berakhir jangka waktunya, maka diharuskan terlebih dahulu melakukan perpanjangan hak atas tanah dengan cara mengurus 
perpanjangan ke Otoritas

Batam (sekarang BP Batam).

Dalam hal ini Notaris harus memastikan bahwa jangka waktu hak tersebut tidak akan berakhir sebelum berakhirnya perjanjian

kredit. Bentuk kehati-hatian ini termasuk jika Notaris atau Pejabat Pembuatan Tanah (PPAT) akan membuat perjanjian take over.

Perjanjian take over merupakan salah satu bentuk perjanjian yang dibolehkan dalam ilmu hukum, sepanjang tidak melanggar peraturan perundang-undangan dan asasasas dalam hukum perjanjian. Perjanjian take over ini dapat dilakukan di hadapan Notaris (notariil) maupun di bawah tangan (tanpa melalui perantara Notaris). Oleh karena itu, perjanjian yang dibuat di hadapan Notaris tersebut merupakan pilihan para pihak (kreditur, debitur awal dan debitur pengganti), akan tetapi dalam prakteknya, pihak perbankan lebih memilih perjanjian take over dilakukan di hadapan Notaris. Hal ini untuk lebih menjamin kepastian dan rasa aman bagi para pihak. Apabila para pihak memilih menggunakan perjanjian take over melalui Notaris, maka muncul persoalan mengenai bagaimana tanggung jawab notaris terhadap perjanjian take over yang dibuatnya.

Apabila para pihak memilih melakukan perjanjian take over tersebut di hadapan Notaris (Notariil), maka perjanjian itu disebut sebagai akta otentik. Dalam Pasal 1868 KUHPerdata ditentukan bahwa "Akta otentik adalah akta yang dibuat dan diresmikan dalam bentuk menurut hukum, oleh atau dihadapan pejabat-pejabat umum, yang berwenang berbuat demikian, dimana akta itu dibuat". Notaris diwajibkan untuk melakukan semua prosesi pembuatan akta perjanjian take over berdasarkan peraturan 
perundang-undangan

yang

berlaku. Ini dilakukan agar akta

Notariil tersebut memiliki

kekuatan

pembuktian

sempurna. Di samping itu,

Notaris perlu juga

memperhatikan kode etik yang berlaku khusus bagi Notaris sebagai pejabat umum.

Untuk mengetahui kaitan pejabat umum dan akta otentik dalam pembuatan akta perjanjian take over, terdapat ketentuan Pasal 1 Peraturan Jabatan Notaris yang menentukan mengenai siapa yang dimaksud dengan notaris, yaitu sebagai berikut: "Notaris adalah pejabat umum (oepenbaar ambtenaar) yang satu-satunya berwenang untuk membuat akta-akta tentang segala tindakan, perjanjian dan keputusan-keputusan yang oleh perundang-undangan umum diwajibkan, atau para yang bersangkutan supaya dinyatakan dalam suatu surat otentik, menetapkan tanggalnya, menyimpan aktanya dan memberikan grosse (salinan sah), salinan dan kutipannya, semuanya itu sepanjang pembuatan akta-akta itu tidak juga diwajibkan kepada pejabat atau khusus menjadi kewajibannya."

Berdasarkan ketentuan di atas, ditegaskan bahwa notaris adalah Pejabat Umum, yang diangkat dan diberhentikan oleh pemerintah dan diberi wewenang dan kewajiban untuk melayani masyarakat. Dalam hal ini, Notaris adalah pejabat umum yang diberi wewenang untuk membuat akta otentik. Keberadaan notaris selaku pejabat umum ini tidak hanya sekedar untuk melayani masyarakat yang membutuhkan jasanya tetapi juga atas perintah undang-undang. Salah satu profesi di bidang hukum, Notaris merupakan pekerjaan dengan keahlian khusus. Jabatan ini menuntut pengetahuam luas serta tanggung jawab dalam melayani kepentingan umum 
dalam setiap pekerjaannya.

Oleh karena itu, dalam setiap akta yang dibuatnya, Notaris perlu memperhatikan dan menjalankan setiap prosedur pembuatan akta sesuai perundang-undangan yang berlaku, termasuk mematuhi kode etik notaris.

Terkait dengan pembuatan akta take over dengan jaminan hak atas tanah, tanggung jawab notaris berlaku juga khususnya dalam hal pembuktian akta apabila terjadi kekhilafan atau kesalahan sehingga akta yang dibuatnya kehilangan otentitasnya.

Berdasarkan tinjauan ilmu hukum, tanggung jawab dalam hukum mempunyai dua dimensi, yaitu tanggung jawab dalam perspektif moral dan tanggung jawab hukum. Notaris memiliki kewajiban melaksanakan tugas dan kewajiban sebaik-baiknya agar tujuan pembuatan akta ini tercapai dan berlaku sebagai akta yang otentik. Hal ini merupakan bentuk pertanggungjawaban Notaris dalam perspektif moral (Soegianto, 2003: 51). Lumban Tobing menyatakan bahwa notaris bertanggung jawab atas akta yang dibuatnya, apabila terdapat alasan sebagai berikut: 1.Di dalam hal-hal yang secara tegas ditentukan oleh Peraturan Jabatan Notaris (sekarang UU Jabatan Notaris).

2.Apabila suatu akta karena tidak memenuhi syaratsyarat mengenai bentuknya (gebrek in de vorm), dibatalkan di muka pengadilan atau dianggap hanya berlaku sebagai akta yang dibuat di bawah tangan.

3.Dengan segala hal, dimana menurut ketentuan-ketentuan dalam Pasal 1365 s/d Pasal 1367 KUH Perdata terdapat kewajiban untuk membayar ganti kerugian, artinya semua hal-hal tersebut harus dilalui pembuktian seimbang. 
Menurut Undang-Undang

Jabatan Notaris, untuk

menentukan

pertanggungjawaban notaris, dalam hal Notaris tidak memenuhi syarat-syarat formil mengenai akta yang dibuatnya, maka akta yang dibuatnya akan kehilangan kekuatan otentitasnya. Hal ini dapat dikualifikasi sebagai penipuan atau muslihat baik yang dilakukan oleh notaris sendiri maupun karena kerjasama dengan pihak yang berkepentingan sehingga akta yang dibuat bertentangan dengan undang-undang kesusilaan atau ketertiban umum. Oleh karena itu, Notaris dapat digugat ganti kerugian, tidak saja oleh pihak atau pihak-pihak yang berkepantingan tetapi juga oleh pihak ketiga, (Soegondo, 1982: 228). Terkait dengan pembuatan akta take over, maka perbuatan melawan hukum yang dilakukan para penghadap juga tidak dapat dinisbatkan kepada notaris.

Secara singkat, berikut akan dibahas mengenai dua aspek penting perihal tanggung jawab hukum notaris, yaitu:

1.Dalam Bidang Hukum

Pidana

Hukum pidana merupakan seperangkat ketentuan sebagai bagian dari hukum publik yang mengutamakan tekanan pada kepentingan umum/masyarakat. Dalam ilmu hukum pidana, untuk menentukan adanya suatu pertanggungjawaban, maka harus dipenuhi 3 (tiga) syarat, yaitu:

a. harus ada suatu perbuatan yang dapat dihukum yang unsurunsurnya secara tegas dirumuskan undangundang.

b. perbuatan tersebut harus bertentangan dengan hukum.

c. harus ada kesalahan pada si pelaku (wederrechtelyjk). 
d. kesalahan/kelalaian

(schuld)

dalam

pengertian

pidana

meliputi unsur-unsur:

1)apabila perbuatan

tersebut bertentangan

dengan hukum

(wederrechtelyk),

2)akibat dari perbuatan tersebut dapat

dibayangkan/ada

penduga-duga

(voorziebaarheid),

3)Akibat itu sebenarnya

dapat

dihindarkan/ada

penghati-hati

(vermijdbaarheid).

Suatu perbuatan atau delik pidana juga dapat

dikualifikasikan dalam dua bentuk yaitu:

a.Yang dilakukan dengan sengaja (opzettelijk, intentional), misalnya

Pasal 23, Pasal 415, Pasal 416, Pasal 417, Pasal 264 ayat (1) KUHP.

b.Yang timbul karena kelalaian (bersoepsfout, negligence). Misalnya Pasal 266 KUHP yang mengatur tentang pemalsuan surat. Menurut paham lama, suatu akta otentik harus menyatakan hal bahwa para pihak telah memberikan keteranganketerangan dan bukan menyatakan kebenaran tentang hal itu (HR 24

Desember 1894 W6606). Menurut paham baru suatu akta otentik yang dibuat oleh notaris gunanya adalah bukan semata-mata untuk membuktikan bahwa para pihak telah memberikan keterangan tertentu di depan notaris, melainkan juga bahwa para pihak itu telah mengadakan perjanjian sesuai ketentuan Pasal 1458 KUHPer, (misalnya dalam jual beli, akta tersebut juga 
membuktikan besarnya

nilai jual beli), jadi

termasuk

pula

kebenaran

dari

keterangan yang telah

diberikan

(HR.

21

Desember

1921.

N.J.1922: 273).

2.Dalam Bidang Hukum

Perdata:

Gugatan dalam proses

perdata

biasanya

menyangkut

gugatan

mengenai tuntutan ganti

rugi. Dasar untuk

pertanggungjawaban profesi

Notaris di bidang hukum perdata adalah:

a.wanprestasi, misalnya

notaris tidak memenuhi

kewajibannya yang

timbul dari adanya suatu

perjanjian.

b.perbuatan melanggar

hukum (onrechmatige

daad), misalnya notaris

telah berbuat melawan

hukum

karena

tindakannya bertentangan

dengan asas kepatutan, ketelitian serta sikap hati-

hati yang diharapkan

darinya dalam pergaulan dengan sesama warga masyarakat.

Terkait dengan pertanggungjawaban Notaris dalam pembuatan perjanjian take over, ketentuan yang biasanya berlaku adalah Pasal 1365 KUH Perdata, mengenai ketentuan perbuatan melanggar hukum. Untuk dapat mengajukan gugatan berdasarkan perbuatan melanggar hukum harus dipenuhi empat syarat seperti yang ditentukan dalam Pasal 1365 KUH Perdata, yaitu:

1.Klien harus mengalami suatu kerugian,

2.Adanya kesalahan atau kelalaian,

3.Ada hubungan kausal antara kerugian dan kesalahan, 4.Perbuatan itu melanggar hukum.

Sebagian pakar hukum yang

lain mengatakan bahwa atas 
pelanggaran

yang

dilakukannya, notaris tidak dapat digugat berdasarkan

wanprestasi

melainkan

berdasarkan

perbuatan

melanggar hukum, alasannya

pada akta yang dibuat

dihadapannya, notaris bukan

salah satu atau pihak yang

terkait dalam akta yang dibuat

itu. Hal tersebut, mengingat

akta yang dibuat dihadapan

notaris merupakan akta pihak-

pihak yang datang menghadap.

Sehingga hubungan hukum

antara notaris dengan klien

bukan hubungan hukum yang

terjadi karena adanya sesuatu

yang diperjanjikan sebagaimana

biasa dilakukan oleh para pihak

dalam membuat suatu

peranjian. Meskipun demikian,

dalam praktek, seringkali

terjadi bahwa akta yang dibuat

dihadapan Notaris kemudian isinya dipersengketakan oleh

para pihak di muka pengadilan.

Dalam hal ini, tidak jarang

Notaris diposisikan pada posisi yang tidak menguntungkan, bahkan dianggap sebagai pihak.

Oleh sebab itu agar melindungi kepentingan Notaris yang bersangkutan, Notaris harus lebih berhati-hati dalam setiap melakukan kewenangannya. UndangUndang Jabatan Notaris menentukan bahwa apabila notaris melakukan kesalahan atau kelalaian dalam menjalankan tugas jabatannya, maka terhadap akta yang dibuat tersebut dapat batal demi hukum atau dapat dimintakan pembatalannya. Berdasarkan ketentuan Pasal 84 dan Pasal 85 UUJN, Notaris dapat dikenakan sanksi perdata dan sanksi administratif).

1.Tindakan Yang Dilakukan Notaris Agar Perjanjian Take Over Dengan Jaminan Hak Atas Tanah Dapat Menjamin Rasa Aman Bagi Para Pihak Secara umum, mekanisme peralihan kredit atau take overdengan jamina hak atas tanah dalam perbankan adalah dimulai dari 
permohonan kredit oleh

debitur. Setelah itu, debitur

menyerahkan

semua

kelengkapan data dan syarat-

syarat pengajuan kredit,

dilanjutkan

dengan

dilakukannya survei oleh

Credit Officer.Apabila oleh

Credit Officer, dianggap

telah memenuhi syarat maka

dilanjutkan

dengan

pembuatan proposal kredit

yang akan diajukan kepada

komite kredit. Apabila

proposal kredit/pembiayaan

tersebut disetujui oleh

komite kredit maka

dilanjutkan

dengan

penandatangan akad kredit

dan pengikatan jaminan yang

wajib dihadiri oleh pihak

bank, debitur dan pasangan.

Setelah

melakukan

pengikatan jaminan, maka

debitur dengan didampingi

marketing atau perwakilan bank

menuju ke kreditur awal untuk

melakukan pelunasan terlebih

dahulu. Apabila pelunasan telah

dilakukan, maka wajib meminta slip tanda pelunasan serta asli

bukti kepemilikan jaminan untuk selanjutnya dapat dibebani Hak Tanggungan dengan terlebih dahulu dilakukan roya (pencoretan hak) atas nama kreditur awal.

Dengan mekanisme seperti ini, maka Notaris melakukan penandatanganan akta akad pembiayaan dan akta pengikatan jaminan SKMHT sebelum surat roya dipastikan terbit pada hari itu juga. Apabila Notaris menggunakan SKMHT sebelum tanggal surat roya dipastikan terbit pada hari yang sama, terjadi pembebanan ulang Hak Tanggungan. Padahal, pada saat pembuatan SKMHT dan Akta Pembebanan Hak Tanggungan, harus sudah ada keyakinan pada Notaris atau PPAT yang bersangkutan bahwa pemberi Hak Tanggungan mempunyai kewenangan untuk melakukan perbuatan hukum terhadap obyek Hak Tanggungan yang dibebankan, walaupun 
kepastian mengenai dimilikinya kewenangan tersebut baru dipersyaratkan pada saat pemberian Hak Tanggungan itu didaftar (Sjahdeini, 1999: 217).

Melihat

konstruksi demikian, sesungguhnya pemberi Hak Tanggungan belum mempunyai kewenangan untuk menguasakan pembebankan Hak Tanggungan yang baru. Hal ini karena Pasal 11 ayat (2) butir g UndangUndang Hak Tanggungan Nomor 4 Tahun 1996 menyebutkan bahwa dalam Akta Pemberian Hak Tanggungan terdapat janji-janji antara lain yaitu janji bahwa pemberi Hak Tanggungan tidak akan melepaskan haknya atas objek Hak Tanggungan tanpa persetujuan tertulis lebih dahulu dari Pemegang Hak Tanggungan (dalam hal ini bank), yang mana bukti tertulis tersebut berupa surat bukti pelunasan hutang dan surat roya. Dilihat dari segi kewenangan, sebagai salah satu syarat sahnya perjanjian menurut Pasal 1320 KUHPerdata, pemberi Hak Tanggungan belumlah sah untuk menguasakan pembebanan Hak Tanggungan yang baru tanpa adanya surat bukti pelunasan atau surat roya dari pemegang Hak Tanggungan, sehingga akta yang dibuat oleh Notaris dapat dipertanyakan keabsahannya.

Akibat dari perbuatan yang dilakukan di atas terhadap akta SKMHT yang dibuat oleh Notaris dapat dibatalkan karena menyalahi salah satu syarat sahnya perjanjian yaitu syarat subjektif mengenai kewenangan dari para pihaknya. Sesuai Pasal 1320 KUHPerdata bahwa syarat sahnya suatu perjanjian yaitu: 1.Sepakat mereka yang mengikatkan dirinya (sepakat).

2.Kecakapan untuk membuat suatu perikatan (kewenangan).

3.Suatu hal tertentu (jelas obyeknya). 
4.Suatu sebab yang halal.

(tidak bertentangan dengan

UU, kesusilaan, dan ketertiban umum).

Syarat pertama dan kedua merupakan syarat subjektif, karena mengenai orang-orang atau subjek yang mengadakan perjanjian, jika syarat subjektif ini dilanggar mengakibatkan akta dapat dibatalkan. Untuk syarat ketiga dan keempat merupakan syarat objektif, karena mengenai isi perjanjian dan jika syarat objektif dilanggar maka akta batal demi hukum (Adjie, 2011: 131).

Apabila surat roya tidak keluar pada hari yang sama dengan penandatanganan akad pembiayaan dan SKMHT, maka akan timbul pertanyaan mengenai bagaimana nilai pembuktian dari akta akad pembiayaan dan SKMHT yang dibuat oleh Notaris tersebut? Terlebih lagi apabila akta tersebut telah diberi tanggal dan nomor untuk kemudian diregister ke dalam buku repertorium Notarispadahal isi yang tercantum didalamnya mengenai pembuktian formal dari akta tersebut belum mengakomodir kenyataan yang ada. Penandatanganan akta akad pembiayaan dan akta pengikatan jaminan seharusnya dilakukan setelah pelunasan, dan setelah surat roya beserta asli sertipikat jaminan keluar sehingga syarat formil dari pembuktian suatu akta seperti hari, tanggal, dan waktunya dapat terpenuhi.

Oleh karena itu, peranan Notaris dalam mewujudkan prinsip kehati-hatian demi perlindungan dan kepastian hukum terhadap para pihak yang terkait di dalam suatu akta sangatlah penting. Ini perlu mendapat perhatian agar tidak terjadi masalah di kemudian hari yang dapat merugikan salah satu atau para pihak dalam akta tersebut, termasuk merugikan diri Notaris sendiri. Di lapangan, sering terjadi bahwa karena posisi Notaris 
yang merasa tidak enak dengan pihak perbankan, maka meskipun syarat-syarat pengikatan jaminan belum memadai, tetap dilakukan pengikatan Notariil. Beberapa Notaris melakukan pengikatan tersebut. Akan tetapi, Notaris sebagai Pejabat Umum tidak boleh tidak, harus mengedepankan prinsip kehatihatian dan menjadikan prinsip kehati-hatian ini menjadi prinsip yang utama demi terjaminnya kepastian dan perlindungan hukum bagi para pihak dalam akta yang dibuatnya dan juga demi perlindungan hukum bagi dirinya sendiri. Halnya jabatan/profesi lainnya, notaris dalam bekerja harus memiliki standar dalam menjalankan setiap kewenangannya. Oleh karena itu, Notaris memiliki kewajiban untuk bersikap profesional. Pasal 16 huruf a UUJN Nomor 30 Tahun 2004 menentukan bahwa Notaris diwajibkan bertindak jujur, seksama, mandiri tidak berpihak dan menjaga kepentingan para pihak yang terkait dalam perbuatan hukum.

Notaris harus senantiasa bertindak amanah, jujur, saksama, mandiri, tidak berpihak, dan menjaga kepentingan pihak yang terkait. Apa yang dimaksud dengan bertindak amanah, jujur, saksama, mandiri, tidak berpihak, dan menjaga kepentingan pihak yang terkait dalam perbuatan hukum? Profesi notaris seperti halnya profesi hukum yang lain, memiliki rumusan kode etik sendiri agar terciptanya suatu keserasian nilai-nilai kaidah dan perilaku. Kode etik ini harus dilaksanakan oleh semua Notaris agar tindakannya selalu sesuai dengan etika profesi. Untuk menjamin kewenangan Notaris dijalankan secara profesional, maka organisasi Notaris (Ikatan Notaris Indonesia) memiliki kode etik Notaris sebagai panduan bagi 
setiap Notaris di seluruh Indonesia. Kode etik pada Pasal 1 angka 2 dimaknai sebagai seluruh kaidah moral yang ditentukan oleh perkumpulan Ikatan Notaris Indonesia yang selanjutnya disebut "perkumpulan" berdasarkan keputusan Kongres

Perkumpulan dan/atau yang ditentukan oleh dan diatur dalam peraturan perundangundangan yang mengatur tentang hal itu dan yang berlaku bagi serta wajib ditaati oleh setiap dan semua anggota perkumpulan dan semua orang yang menjalankan tugas jabatan sebagai notaris, termasuk di dalamnya para Pejabat

Sementara Notaris. Notaris Pengganti dan Notaris Pengganti Khusus."

IV. SIMPULAN DAN SARAN

\subsection{Simpulan}

Berdasarkan uraian-uraian tersebut di atas, maka dapat ditarik kesimpulan terhadap permasalahan yang dibahas antara lain sebagai berikut:

1.Dalam pembuatan akta perjanjian take over, pada hakekatnya Notaris memiliki tanggung jawab baik secara moral maupun hukum. Tanggung jawab moral meliputi antar lain meliputi kewajiban Notaris untuk melaksanakan tugas dan kewajiban sebaik-baiknya agar tujuan pembuatan akta ini tercapai dan berlaku sebagai akta yang otentik. Tanggung jawab hukum meliputi tanggung jawab di bidang hukum perdata maupun pidana. Tanggung jawab dibidang hukum perdata terkait dengan potensi digugatnya Notaris atas akta perjanjian take over yang ia buat. Gugatan dari klien dapat berupa gugatan wanprestasi maupun gugatan perbuatan melawan hukum (onrechtmatigedaad). Tanggung jawab dibidang hukum pidana meliputi 
potensi delik pidana yang mungkin dilakukan Notaris baik yang dilakukan dengan sengaja (opzettelijk, intentional), misalnya Pasal 23 KUHP, Pasal 415, Pasal 416, Pasal 417 KUHP, Pasal 264 ayat (1) KUHP, maupun yang timbul karena kelalaian (bersoepsfout, negligence), seperti pelanggaran Pasal 266 KUHP yang mengatur tentang pemalsuan surat. Akan tetapi, yang harus diperhatikan bahwa Notaris tidak bertanggung jawab atas perbuatan-perbuatan

melanggar hukum yang dilakukan oleh para pihak yang menghadap Notaris yang bersangkutan.

2.Agar setiap akta khususnya yang terkait dengan perjanjian take over dengan jaminan hak atas tanah dapat menjamin rasa aman bagi para pihak, maka Notaris wajib untuk melaksanakan berbagai peraturan perundang-undangan yang belaku. Notaris wajib memahami dan melaksanakan ketentuan Undang-undang Nomor 30 Tahun 2004 sebagaimana telah diubah dengan Nomor 2 Tahun 2014 tentang Jabatan Notaris serta Kode Etik Notaris yang dibuat oleh perkumpulan (Ikatan Notaris Indonesia). Ketentuan tersebut mewajibkan Notaris agar bertindak jujur, seksama, mandiri tidak berpihak dan menjaga kepentingan para pihak yang terkait dalam perbuatan hukum. Notaris juga harus senantiasa bertindak amanah, jujur, saksama, mandiri, tidak berpihak, dan menjaga kepentingan pihak yang terkait. Di samping itu, Notaris wajib merahasiakan isi akta dan keterangan yang diperoleh dalam pembuatan akta Notaris, kecuali diperintahkan oleh undangundang bahwa Notaris tidak 
wajib merahasiakan dan

memberikan keterangan yang diperlukan yang berkaitan dengan akta tersebut. Notaris juga harus memegang teguh prinsip kehati-hatian, oleh sebab pertanggungjawaban seorang Notaris terhadap akta yang dibuatnya adalah seumur hidup.

\subsection{Saran}

Adapun saran yang dapat diberikan dari kesimpulan terhadap permasalahan yang dibahas antara lain sebagai berikut:

1.Dalam pembuatan akta perjanjian take over, pada hakekatnya Notaris memiliki tanggung jawab baik secara moral maupun hukum, tetapi tanggung jawab yang telah diberikan Negara jangan sampai disalahgunakan. Apabila klien salah notaris wajib memberikan solusi agar perbuatan yang salah tersebut tidak terlaksana karena tanggungjawab notaris sekarang tidak hanya sebagai saksi, tetapi notaris dapat dilibatkan apabila notarisnya juga ikut serta melakukan pelanggaran hukum atau kejahatan hukum.

2.Agar setiap akta khususnya yang terkait dengan perjanjian take over dengan jaminan hak atas tanah dapat menjamin rasa aman bagi para pihak, maka notaris harus banyak memahami aturan yang berlaku, sehingga sebelum masyarakat membuat akta kepada notaris maka notaris dapat memberikan saran sesuai dengan bidang keilmuannya.

\section{DAFTAR PUSTAKA}

Buku-buku, Jurnal Dan Makalah

Adityananta, Samuel. 2013. Perlindungan Hukum Pada Nasabah Bank Atas 
Jurnal Cahaya Keadilan . Vol 5. No. 1 ISSN: 2339-1693

Sebagian Dana Yang

Hukum,

Hilang Akibat Kartu

Februari

Anjungan Tunai Mandiri

Universitas Jambi.

(ATM) Yang Tertelan

Djumhana, Muhammad. 2000.

Dalam Mesin ATM

Hukum Perbankan di

Berdasarkan Undang-

Undang Nomor 8 Tahun

Indonesia. Citra Aditya

1999 Tentang

Perlindungan Konsumen.

Jurnal Calyptra. Jurnal

Ilmiah Mahasiswa

Universitas Surabaya

Volume 2. Nomor 2.

Adjie. Habib. 2008, Hukum

Notaris Indonesia (Tafsir

Tematik Terhadap

Undang-Undang Nomor

30 Tahun 2004 tentang

Jabatan Notaris).

Bandung,Refika Aditama.

Ais, Chatamarrasjid. 2011.

Hukum Perbankan

Nasional Indonesia.

Kencana. Jakarta.

Asmawati. 2015. Analisis

Yuridis Penyalahgunaan

Kartu Kredit Terhadap

Para Pihak Dalam

Perjanjian Jual Beli.Vol

6, No1: Jurnal Ilmu

Bakti. Bandung.

Erdiansyah. 2012. Penerapan

Prinsip Mengenal

Nasabah Sebagai Bentuk

Peranan Bank Dalam

Mengantisipasi Tindak

Pidana Pencucian Uang

(Money Laundering)

Pada PT Bank Negara

Indonesia (Persero) Tbk

Cabang Pekanbaru.

Jurnal Ilmu Hukum UNRI

Volume 3 Nomor.

1.

Pekanbaru.

Harun, $\quad$ Badriyah. 2010. Penyelesaian Sengketa

Kredit Bermasalah,

Solusi Hukum (Legal

Action) dan Alternatif

Penyelesaian Segala

Jenis Kredit Bermasalah.

Penerbit Pustaka Yustisia.

Yogyakarta.

Hasibuan, Malayu. 2008.

Dasar-dasar Perbankan. 
Bumi Aksara.Jakarta.

Kie, Tan Thong. 2007. Studi

Notariat dan serba-serbi

Praktek Notaris. PT

Ichtiar Bari Van Hoeve.

Jakarta.

Moleong, Lexy J. 2012.

Metodologi Penelitian

Kualitatif. PT Remaja

Rosdakarya. Bandung.

Mulyoto. 2010. Kriminalisasi

Notaris

Dalam

Pembuatan

Akta

Perseroan

Terbatas.

Yogyakarta. Cakrawala.

Notodisoejo, R. Soegondo,

1982 Hukum Notariat Di

Indonesia, suatu

penjelasan, Jakarta: CV.

Rajawali.

Satrio, J. 1999. Cessie,

Subrogatie, Novatie,

kompensatie dan

Percampuran Hutang.

Alumni. Bandung.

Sjahdeini,Remy, 1999, Hak

Tanggungan Asas-asas

Ketentuan-ketentuan

Pokok danMasalah yang

Dihadapi

oleh
Perbankan,Penerbit

Alumni, Bandung.

Sjaifurrachman, Habib Adjie, 2011, Aspek

PertanggungjawabanNot

aris

dalam

PembuatanAkta,Mandar

Maju, Bandung.

Soegianto, 2003 Tanggung Jawab Pendiri dan

Notaris dalam Kaitannya

Dengan Penyetoran

Modal Untuk Pembuatan

Akta

Pendirian

Perseroan, Tesis :

Universitas Diponegoro

Semarang Terbatas.

Soerjopratiknjo, Hartono. 1984.

Hutang

Piutang

Perjanjian-perjanjian

Pembayaran dan Jaminan

Hypotik. Yogyakarta.

Seksi Notariat Fakultas

Hukum Universitas

Gadjah Mada Yogyakarta.

Sulastri, Sri. 2011. Akibat

Hukum

Terhadap

Perjanjian

Hutang

Menurut KUH Perdata.

Jurnal

Yustitia. 
Universitas

Madura.

Volume 11, No.1 Mei 2011.

Sundah, Pingkan. 2014.

Tinjauan

Yuridis

Terhadap

Tidak

Dilaksanakannya

Kewajiban

Jabatan

Notaris Menurut Undang-

undang No. 2 Tahun

2014. Jurnal Lex et

Societatis. Vol. II/No.

4/Mei/2014.

Suwandi, Gunarto. 2006. Resiko

Dalam Pemberian Kredit

Perbankan. Jurnal Hukum

Projustitia. Januari 2006,

Volume 24 No. 1.

Suwardi, Raga Taufani. 2010.

Tanggung Jawab Bank

Akibat Kerugian Diderita

Oleh Nasabah. Jurnal

Hukum. Vol. XVIII,

Nomor 18, April 2010.

Taufik, Ady Imam. 2011. Agar

KPR Langsung Disetujui

Bank.

MedPress.Yogyakarta.

Usanti, Trisadini Prasastinah.

2013. Akad Baku Pada
Pembiayaan Murabahah

di Bank Syariah.

Perspektif. Volume

XVIII Nomor 1 Tahun

2013 Edisi Januari.

Witasari, Aryani. 2012. MPD

Bukan Advokat Para

Notaris Berdasarkan

Undang-Undang No.30

Tahun 2004 Tentang

Jabatan Notaris. Jurnal

Hukum. Vol XXVIII, No.

2, Desember 2012.

Zizaldy, Muhammad, 2015.

Pelaksanaan Take Over

Pembiayaan di PT. Bank

Syariah Mandiri Cabang

Medan. Premise Law. Vol

12. USU. Medan.

Peraturan

Perundang-

\section{Undangan}

Undang-Undang

Dasar

Republik

Indonesia Tahun 1945.

Kitab Undang-Undang Hukum

Perdata (BW). 